Linda Martín Alcoff and John D. Caputo (Editors)

\title{
Feminism, Sexuality, and the Return of Religion
}

BLOOMINGTON AND INDIANAPOLIS: INDIANA UNIVERSITY PRESS, 2011

Reviewed by Krista Hyde

Narrated by Kelsey Borrowman

\section{"This collection charts new ground, inviting feminist theory to collaborate with theology on sexuality, gender, and philosophy, along with themes of violence, The Gift, the power of God-language, divine indeterminacy, and the breaking of binaries."}

Never before in a single collection have such diverse authors converged to theorize on feminist theory and its relation to contemporary continental philosophy of religion. The title and subject of this collection, Feminism, Sexuality, and the Return of Religion, assumes that religion has made a comeback since its Enlightenment-era banishment. This resurgence, however, is alongside potentially inconsistent forces: feminism and sexuality. The authors in this collection attempt to dislodge our intuitions that religion and sex are in opposition, despite such challenges as the weight of scripture and the historical problems of masculine God-language, devaluation of the body and sexuality, and obsession with asceticism and purity.

Women's resistance within these traditions is paramount in the collection, which describes the destruction of hierarchies of sex and religion that make room for cultures of women's own creation. Further, the universal is not theorized at the expense of the contextualized, particular experience of a woman. This collection charts new ground, inviting feminist theory to collaborate with theology on sexuality, gender, and philosophy, along with themes of violence, The Gift, the power of God-language, divine indeterminacy, and the breaking of binaries.

The theme of The Gift threads through Catherine Keller's "Returning God: The Gift of Feminist Theology" and into Sarah Coakley's "In Defense of Sacrifice." Keller's essay pursues the relationship between the return of religion and the "returning God" of feminist theology, evidence for which is found in the intensity of debate around God-language. She struggles with a feminist God whose history is that of a man. Upon God's death, many hoped for the stability of a nurturing Mother; this failed to materialize, so some feminist theologians gave God back, returning the Gift and leaving theology. Those who stay risk some death of identity along with receiving some gift, as is expected for women who wish to participate in the fullness of life in a culture of misogyny.

The dualistic opposition of the patriarchal divine to secularism continues, with feminist theologians facing the death of feminist theology, struggling to put theory into action, and still stumbling self-consciously on "Our Mother, who art in heaven." Keller's answer is a third, open, fluid alternative: uncertainty. Uncertainty is not the enemy in theology; attempts to categorize divine love fail because it cannot be contained. Institutionalization does not suit it. God was, after all, made flesh.

Keller reverses the discussion, offering the gift of indeterminacy to the returning God. She reads the ambiguity of feminist theology, exemplified in the undecidedness of God-language among feminist theologians, as reception of the Gift and openness to possibility. That we cannot make a final decision about the feminine name of God, or the feminine expression of God, is an extension of the long tradition of God's many names.

Sarah Coakley's essay approaches that most difficult of scriptural texts, the akedah, to reinterpret the concept of sacrifice. "In Defense of Sacrifice: Gender, Selfhood, and the Binding of Isaac" is feminist midrash that offers the bound Isaac as feminist hero, consenting to divine intervention at his father's threatened violence. For Coakley, sex, feminism, and the return of religion intersect at just this point: modern feminism offers agency, sexuality offers desire and its satisfaction, but the two are troubled and cannot converge without God. 
Coakley "kidnaps" Isaac in a startling rereading of the Abraham and Isaac drama. Isaac, in the position of the modern/postmodern woman with desires and responsibilities outside the home but without the power to realize them, is further endangered by a false logic of patriarchal sacrifice. In this reimagining, she draws on the strand of Jewish thought that maintains Isaac was an adult at the time of the sacrifice, who bound himself in an act of consent.

Essential to this exegesis is the distinction in Jewish and Christian thought between false and full (authentic) sacrifice; that is, both traditions recognize that one can authentically consent to sacrificial intention that is ultimately aimed at flourishing, whereas false sacrifice accepts artificial consent and tends to abuse and violence. The analogy to the working woman is clear: she appears to submit to the false logic of patriarchal sacrifice but makes an authentic purification aimed at fullness of life. However, her submission is not to abuse and violence, and her suffering is allowed only until she is redeemed. In this way, false sacrifice becomes pure gift, as when Isaac is replaced by the ram on the sacrificial altar.

Sexuality and gender are related to this sacrificial nexus; authentic sacrifice is the only thing that accounts for the feminist transformation of the self from the bondage of gender binaries into true freedom. Sexuality, as the primary reminder of our embodied selves and their reliance on God, thus ties us--by our consent--to God. Divine interruption frees the feminist to rethink the concepts of God, sexuality, and gender. Sacrifice purges false desire but leads ultimately to life, freedom, and connection with others.

The theme of problematic duality is continued in Mark Jordan's "The Return of Religion during the Reign of Sexuality," which compares the careers of two sovereigns: the previous reign of Christianity, and the current monarchy of "King Sex." Jordan questions whether religion can return, since he posits that it never really left. That is, though the secular has ostensibly taken over our public spaces, Christianity continues to rule by occupation of worldview. The idea that Christianity has been banished is dependent on confusion about what it means to end the official relationship of church and government, as well as a misunderstanding about sex.

It was thought that sex, or at least the sexual revolution, would free us from theology, but it is clear now that Christianity's dominance and political action does not depend on our sexual repression. Though there has been a change in the balance of power, and now Sex sits on the throne, God has operatives in the castle. Further, God and Sex aren't unrelated. Announcing the death of God opened the door to Sex, but it also meant bringing sex under the management of the heterosexual family and fertility. Jordan explains that the Christian God had to be displaced because of His sexlessness, but the return of His Other means adopting an "equally closed system."

What to do about this situation? Redemption is made possible by looking at Jesus' silence on the subject of sex. Instead of searching for a new law, focusing on purity of the body, Jordan searches for characters of desire, parables of the erotic, which can be approached ritually, as participation in liturgy is participation in the power of God.

Saba Mahmood's "Religion, Feminism, and Empire: The New Ambassadors of Islamophobia" discusses questions of violence and religion. Her essay describes the new, autobiographical genre of nonfiction books about the lives of Muslim women living under misogynistic traditions, which she maintains is political rhetoric. The books champion religious and cultural reform of "fundamentalist" Muslim oppression of women, justifying Western imperialism. These biographies argue that bringing democracy to the Muslim world will reverse the victimhood of Muslim women, but this is another example of the politics of empire, tied to colonialist discourse that justified religious and political reform to "liberate" indigenous women from native patriarchal cultures.

The model of empowerment and emancipation that threads through these books makes them popular with feminist critics, but Mahmood gives a compelling argument for engaging and respecting the religious commitments of Muslim women. She exposes the autobiographies as just so much propaganda in her compelling account, which demonstrates the conservative political patronage and compensation behind 
them. The authors often have relationships with, and their accounts typically parallel the policies of, conservative political parties and think tanks, lending credence to her claim that they serve the political purposes of conservative agendas.

Further, the books are full of historical inaccuracies and factual errors; they give the impression that the Islamic world is of one (exceedingly sexist) mind. The accounts are hyperbolic and systematically exclude information that challenges stereotypes; as such, they assist in building support for Muslim opposition, giving credibility to prejudice. The role of the "oppressed Muslim woman" is to forward arguments for geopolitical domination, and as such, the authors' Muslim identities give credence to views that would otherwise be suspect.

Without disregarding the atrocities women suffer in Islamic and other societies, Mahmood calls for a critical reading of such texts. The current "war on terror" also includes a war against Islam, and targets not just terrorists or militants, but all traditional Muslims. Calls for liberalization of Islam and democratization of the Muslim world assume a conception of religion as personal and private systems of beliefs, presupposing autonomous individuality and separating religion's phenomenal forms from its universal truths. This severely curtails the forms of religious understanding available to Muslim women and undermines their epistemic authority. Calls for secularization are importantly problematic because of their rejection of difference in forms of religion and worldview.

In "It's All about the Blues: The Black Female Body and Womanist God-Talk," Kelly Brown Douglas pursues the compatibility of Christianity with black women's identity, tying the themes of the book with the role of Christianity in exploitation and manipulation of the black female body. She is convinced that sexuality, our need to physically and spiritually commune with others, is related to religion: one's relationship to the transcendent is possible only when one can affirm oneself sexually. Douglas explores essentialism in her religious tradition, and the manner by which it demonizes sexuality, which is problematic for black female bodies.

Douglas takes this schema, applying it to the tradition of blues-singing women, to describe the complexity of black women's oppression and the role of religion therein. As black bodies have been stereotyped as highly sexualized by white supremacist culture (in order to question the very humanity of black persons), the black American religious tradition has adopted a Platonic Christianity, which splits the body from the soul and thus severs the link between blackness and sexuality. This allows black church people to reject the stereotype of hypersexuality and reclaim their human nature.

The blues tradition, however, is one of explicit sexuality, not as stereotype affirmation but as subversion and in protest. As such, women blues singers singing about sexuality determine their own bodies, claiming freedom by asserting sexual agency. This, however, alienates them from black church culture, so it is not entirely empowering. These two can be reconciled through African tradition, which points out Christianity's incarnate and embodied nature. Further, African religion rejects the Platonic sacred/secular split, affirming the sanctity of sexuality and the body. In this way, Douglas answers the tension between being an AfricanAmerican woman and feminist and being a Christian.

Hélène Cixous, in "Promised Belief," renews the collection's theme of God-language and God's name. In the essay, she describes her collection of short stories, The First Name of God, and the discussion it prompted with her friend Jacques Derrida; the two, in dialectic, continuously changed "sides" of the God debate, always reminding each other what side they were arguing--an expression of the continuous interrelation of God, language, and literature.

In the essay, Cixous describes the power of language around religion: All the words spoken about God create God and God's power; belief in that power makes it so, just as speaking a thing makes it possible. As such, it is fitting that the Jewish people refuse to speak God's name. God is, after all, all the things we think about but refuse to speak aloud. She depicts speaking about God to Derrida, then writing about God, in a 
cycle in which she finds herself won over, and in which she finally understands what he means when he says, "we die in the end, too fast."

She also broaches the topic of violence, one so often coupled with religion, and recognizes that a concept this powerful must necessarily be wrapped up with politics. Thus, politics, violence, and religion all come to bear on women's liberation. God and violence come wrapped up in fear, which leads to both faith and its loss. God, beyond understanding, means living and death--because of that faith and its promise of the cycle of starting over; as she says, "I'm forever having to begin all over again." As such, fear of God is also linked to love. Her love for Derrida and her description of their relationship, in the face of his continued illness, occurs over the course of a conversation lasting many years.

Gianni Vattimo, in "Nihilism, Sexuality, Postmodern Christianity," proposes an alternative to the naturalistic Christianity currently on offer, and maintains that nihilism can save Christianity from irrelevancy. He maintains that a postmodern interpretation of Christianity provides a promising model that defends human essence, and argues the Church is amiss in maintaining natural-law philosophy, as Jesus came to the world not to preserve the natural order, but to destroy it. As such, when the Church argues against the existence of women priests or against same-sex marriage, it counters Jesus' message and idolizes the natural order.

Drawing on Habermas and Heidegger, Vattimo maintains that in the age of science and technology, the natural order no longer holds authority. Given the acceptance of physical explanations of the universe, he proposes a Christianity focused on salvation and the Second Coming in nonmetaphysical terms. He refuses to fear for his faith in the face of scientific cosmology, and maintains that the Church should accept science's view of the natural world. By this he does not intend an atheistic cosmology but an informed sexuality. Jesus focused on charity, he reminds the reader, not on nature.

Vattimo argues that sexuality is a bioethical issue. Just as Christian parents should accept "unnatural" interventions, such as inoculations, that prevent their children from disease, so too should the Church accept so-called unnatural sexuality. Insisting on the reproductive legitimacy of sexuality has nothing to do with the revolution Jesus began. To continue that revolution, the author argues for the rejection of naturalism in the Church, and the acceptance of a nihilistic alternative, one that focuses on the disruptive nature of Jesus's role in the world.

The collection concludes with a roundtable in which the authors and editors bring the many themes together. Feminism, sexuality, and the return of religion, the stated topics of the book, are structured by parallel themes of the deconstruction of God-language, the reparation of the religious approach to sexuality, and the hegemony of Christian assumptions about the study of religion. The authors deal with the appropriate response, if any, of feminism and sexual liberation to the return of religion, and what the future of these will entail. This is certainly a welcome addition to the library of philosophers of religion, as well as feminist and gender theorists and students.

Krista Hyde is a PhD student in philosophy at Saint Louis University. Her research interests include philosophy of religion, ethics, and the history of philosophy. Prior to entering the program at SLU, she earned a master's degree (also in philosophy) from the University of Missouri-St. Louis. Her master's thesis, "Thomas Aquinas: Mind-Body Connection and the Afterlife" explores the relationship between Thomistic psychology and claims about the afterlife. Previously, she earned a Master of Liberal Arts at Washington University in St. Louis, writing a thesis on the application of environmental ethics to halacha.

khyde5@slu.edu 